\title{
Evaluation of the effects of subcostal transversus abdominis plane block on acute and subacute pain development following inguinal herniography: Randomized clinical study
}

\author{
Subkostal transversus abdominal plan bloğun mesh ile inguinal herniorafi sonrası akut ve \\ subakut ağrı gelişimi üzerine etkisinin araştırılması: Randomize, klinik çalışma
}

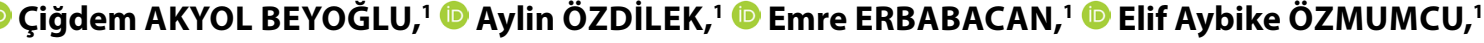

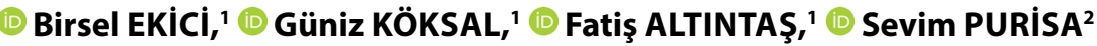

\begin{abstract}
Summary
Objectives: The effect of subcostal transversus abdominis plane (TAP) block on postoperative pain is contradictive. The aim of this study was to evaluate the effect of subcostal TAP block on subacute pain in patients who have undergone inguinal herniography.

Methods: Patients aged between 18 and 75 years with American Society of Anesthesiologists 1-3 and who were to undergo elective unilateral inguinal herniography with mesh under general anesthesia were included. Fifty patients were under an intravenous analgesic regimen (group I) and 50 patients underwent subcostal TAP block postoperatively in addition to the intravenous analgesic regimen (group II). The primary outcome measure was pain scores 1 month postoperatively by comparing Numerical Rating Scale values with the Mann-Whitney U test between groups I and II. Secondary outcome measures were life qualification scores 1 month postoperatively and pain scores $24 \mathrm{~h}$ and 15 days postoperatively.

Results: Postoperative $15^{\text {th }}-\min ; 1^{\text {st }}, 6^{\text {th }},-12^{\text {th }}$, and $24^{\text {th }}$-h; $15^{\text {th }}$-day $(\mathrm{p}=0.00)$; and $1^{\text {st }}$-month Numerical Rating Scale values were significantly lower in group II than in group I $(p=0.02)$. No significant difference was observed between the groups in terms of LQS 15 days postoperatively $(p=0.013)$. On group comparison, $L Q S$ was higher in the $1^{\text {st }}$ month than at the $15^{\text {th }}$ day postoperatively in group I $(p=0.201)$.

Conclusion: Subcostal TAP block provides an effective postoperative pain treatment in the acute period and in the $1^{\text {st }}$ postoperative month in patients undergoing inguinal herniography.
\end{abstract}

Keywords: Inguinal herniography; postoperative subacute pain; subcostal transversus abdominis plane block.

\begin{abstract}
Özet
Amaç: Subkostal transvers abdominis plan bloğunun (TAP) postoperatif ağrı üzerindeki etkisi halen araştırma konusudur. Bu çalışmanın amacı, inguinal herniorafi hastalarında postoperatif subakut ağı üzerine subkostal TAP bloğunun etkisini değerlendirmektir.

Gereç ve Yöntem: Genel Anestezi altında mesh ile elektif tek taraflı inguinal herniyorafi geçirecek olan 18-75 yaş arasındaki ASA skoru 1-3 olan hastalar çalışmaya alınmıştır. Elli hastaya postoperatif ağrı tedavisi için iv analjezik verildi (grup I), elli hastaya operasyondan sonra iv analjeziye ek olarak subkostal TAP blok uygulandı (grup II). Operasyondan 1 ay sonra gruplar arası numerik ağrı skalası Mann-Whitney U testi ile karşılaştırdı. Hastaların operasyondan sonra 15. Dakika. 1, 6, 12, 24. saat, 15. gün NRS skorları ile 15 gün ve 1 ay sonraki yaşam kalitesi skorları (LQS) değerlendirildi.

Bulgular: Postoperatif 15. dakika, 1, 6, 12, 24. saat, 15. gün ( $p=0.00$ ) ve 1. aydaki NRS değerleri grup II'de grup l'e göre anlamlı derecede düşük bulundu ( $p=0.02$ ). Ameliyattan 15 gün sonra LQS açısından gruplar arasında anlamlı fark yoktu ( $p=0.013)$. Gruplar arası karşılaştırmada LQS birinci ayda Grup I'deki postoperatif 15. güne kıyasla daha yüksekti $(p=0.201)$.

Sonuç: Subkostal TAP bloğu akut dönemde ve inguinal herniorafi yapılan hastalarda ameliyat sonrası ilk ayda etkili bir postoperatif ağrı tedavisi sağlamaktadır.
\end{abstract}

Anahtar sözcükler: Inguinal herniorafi; postoperatif subakut ağrı; subkostal transvers abdominis plan bloğu.

'Department of Anesthesiology and Reanimation, Istanbul University Cerrahpaşa Faculty of Medicine, Istanbul, Turkey
'Department of Pharmaceutical Technology, Istanbul University Faculty of Pharmacy, Istanbul Turkey

Submitted (Başvuru tarihi) 08.01.2018 Accepted after revision (Düzeltme sonrası kabul tarihi) 19.03.2018 Available online date (Online yayımlanma tarihi) 25.06.2018

Correspondence: Dr. Çiğdem Akyol Beyoğlu. Istanbul University Cerrahpasa Medical Faculty, Kocamustafapasa Street No: 53, 34098 Fatih, Istanbul, Turkey.

Phone: +90 - 212 - 4143000 e-mail: akyolbeyoglu@gmail.com

(c) 2018 Turkish Society of Algology 


\section{Introduction}

Inguinal hernia repair is one of the most common surgeries performed by the general surgeons. Following herniography, neuropathic pain related to neuronal injury or nociceptive pain due to tissue damage may be observed. Occurrence of postoperative pain can influence the quality of life of patients and result in the manifestation of chronic pain. ${ }^{[1]}$

Use of mesh for inguinal hernia repair is established as a golden standard. However, postoperative chronic inflammation surrounding the "mesh" can cause chronic nociceptive pain. ${ }^{[1]}$ Chronic pain incidence is up to $11 \%$ after inguinal hernia repair with mesh. ${ }^{[2]}$ It complicates the patients' return to normal daily physical activities and negatively affects their quality of life.

Transversus abdominis plane (TAP) block is a regional anesthesia technique that blocks afferent nerve induction arising from the anterolateral abdominal wall. ${ }^{[3]}$ The three muscles in the anterolateral region associated with TAP block are external oblique, internal oblique, and transversus abdominis muscles. ${ }^{[4]}$ This region (skin, muscles, and parietal peritoneum) is innerved by the anterior branches of T7-L1 spinal nerves. ${ }^{[3]}$ Intercostal (T9-T11), subcostal (T12), ilioinguinal, (L1) and iliohypogastric (T12-L1) nerves travel through the space described as TAP. It is a space between the internal oblique and transversus abdominis muscles. ${ }^{[4]}$ The aim of TAP block is to infiltrate this space with intermediate and long-acting local anesthetics and block T6-L1 spinal afferent nerves of the anterior abdominal wall. This block is not only effective on pain resulting from the skin and the abdominal wall but is also effective on pain related to parietal peritoneum. The block can be performed using subcostal, midaxillary, or posterior approaches. Studies show that local anesthetic distribution differs with different approaches used..$^{[5]}$

With the subcostal approach, the local anesthetics spread to the fascia between the two muscle layers where the transversus abdominis muscle separate from the rectus abdominis muscle (Fig. 1).

TAP block can be performed using anatomical landmarks or with the guidance of ultrasonography. Ultrasonography enables the performer to observe local anesthesia distribution to the targeted area.
In our study, we aimed to evaluate effects of subcostal TAP block on acute and subacute pain development and quality of life in the $1^{\text {st }}$ postoperative month in patients who underwent inguinal herniography.

\section{Material and Methods}

The study was in accordance with the Declaration of Helsinki and Guidelines for Good Clinical Practice and registered at ClinicalTrials.gov with the number NCT02914028. Following approval from the ethics committee of the Istanbul University, Cerrahpasa Faculty of Medicine (Chairperson Professor Ozgur Kasapcopur) on December $1^{\text {th }}, 2015$ (protocol ID: 235901) (Address: Istanbul University, Medical School of Cerrahpasa, 34098 Cerrahpasa-Fatih/istanbul), and obtaining written informed consent from the patients, this prospective randomized clinical study included 100 ASA I-III patients aged between 18 and 75 years and who were to undergo elective unilateral inguinal herniography with "mesh" under general anesthesia. Fifty patients were under an intravenous (iv) analgesic regimen (group I) and 50 patients underwent subcostal TAP block postoperatively in addition to the iv analgesic regimen (group II). Patients who had relevant drug allergy and infection at the injection site were excluded from the study.

Patients' demographics (height, body weight, age, gender, and ASA status) were recorded. Patients were randomized into the two groups using a closed enve-

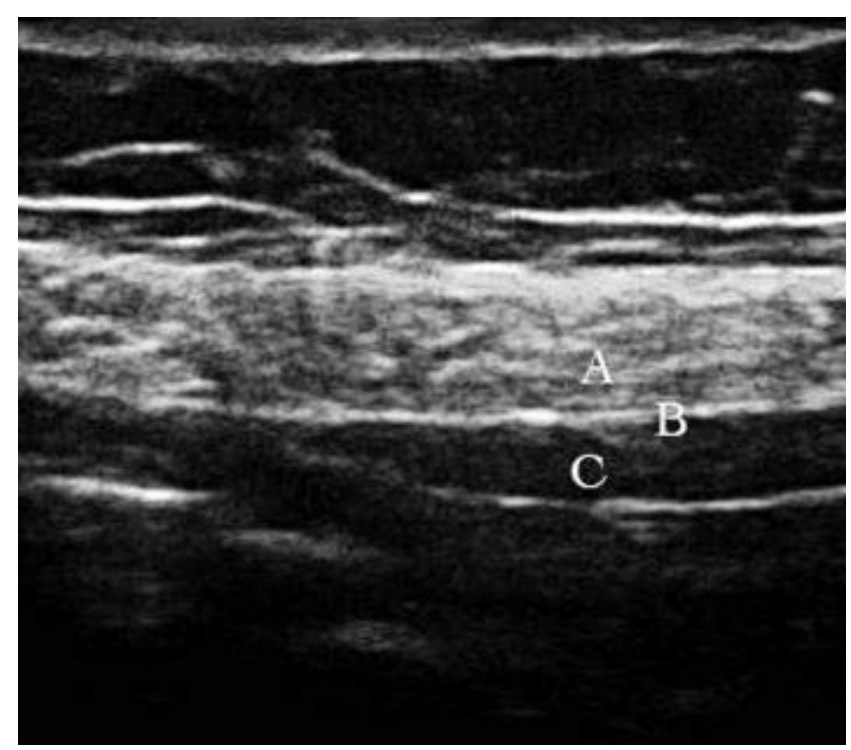

Figure 1. Before block. (a) Musculus rectus abdominis. (b) Fascia between the rectus and transversus muscles. (c) Musculus transversus abdominis. 
lope technique. A 20-gauge cannula was inserted on the dorsum of the left hand of the patients who were taken into the preoperative anesthesia room and 0.03 $\mathrm{mg} / \mathrm{kg}$ iv midazolam (Zolamid $15 \mathrm{mg} / 3 \mathrm{ml} \mathrm{amp}$, Defarma, Turkey) was administered, and $8 \mathrm{ml} / \mathrm{kg}$ Isolyte $\mathrm{S}$ (1000 ml PVC/Ezacibasi/Baxter, Turkey) infusion was initiated. Patients were taken to the operation room, and standard monitorization was done (ECG, noninvasive arterial blood pressure, and peripheral oxygen saturation). Anesthesia was induced with $2 \mathrm{mg} /$ kg propofol (propofol 1\%, Fresenius, Fresenius Kabi, Germany), $0.6 \mathrm{mg} / \mathrm{kg}$ rocuronium (Curon $50 \mathrm{mg} / 5$ $\mathrm{ml}$, Mustafa Nevzat, Turkey), $1 \mu \mathrm{g} / \mathrm{kg}$ fentanyl (Talinat $0.5 \mathrm{mg} / 10 \mathrm{ml}$, VEM, Turkey), and anesthesia was maintained with $2 \%$ sevoflurane (Sevorane, Abbott, Turkey) in 40\%/60\% $\mathrm{O}_{2}$ /air mixture. All patients were ventilated at pressure-controlled ventilation mode with the parameters of Psupport maintaining 6-8 ml/ $\mathrm{kg}$ tidal volume, $\mathrm{FiO}_{2}: 40 \%$, I:E 1/2, PEEP: $7 \mathrm{cmH}_{2} \mathrm{O}$, frequency: $12 /$ min supporting $\mathrm{ETCO}_{2}$ value between 32 and36 $\mathrm{mmHg}$. When the intraoperative systolic arterial pressure or heart rate increased $20 \%$ compared with the initial values, an additional fentanyl dose of $50 \mathrm{mcg}$ IV was administered.

During close-up of the surgery, patients in both groups were given $100 \mathrm{mg}$ tramadol (Ultramex 100 $\mathrm{mg}$, Adeka Medical, Turkey) and $1 \mathrm{~g}$ paracetamol IV (Parol 10 mg/ml, Atabay Medical, Turkey).

At the end of the surgery, anterior and lateral regions of the abdominal wall of patients in group II had been cleaned with $10 \%$ povidone iodine solution. The ultrasound probe (EsaoteMylab 30; Esaote, Florance, Italy) was covered with a sterile plastic camera cover and was placed to the lateral sheath of the rectus abdominis muscle on the subcostal area. The medial border of the transversus abdominis muscle and its fascia was visualized. A 21-gauge, 100-mm Quincke needle (Stimuplex A 100 mm; Braun, Mesulgen AG, Mesulgen, Germany) was anteriorly introduced in the plane of the ultrasound probe passing through the skin and subcutan tissues and entered into the fascia of musculus transversus abdominis. Following negative aspiration, $2-3 \mathrm{ml}$ of $0.9 \% \mathrm{NaCl}$ was injected to proof the correct position (Fig. 2). After verifiying the spread of the injectate in the TAP fascia, bupivacaine (Marcaine 0.5\%, $20 \mathrm{ml}$ flk, Astra Zeneca, England) $10 \mathrm{ml}, 1 \%$ lidocaine (Aritmal 2\%, Osel, Turkey)
$10 \mathrm{ml}$, and $0.9 \% \mathrm{NaCl} 10 \mathrm{ml}$ were injected to the TAP fascia in a total of $30 \mathrm{ml}$ solution. Patients in group I did not receive any additional pain treatment besides iv tramadol and paracetamol.

Patients in both groups were given $1 \mathrm{mg} / \mathrm{kg}$ atropine (atrophine sulfate, $1 \mathrm{mg} / \mathrm{ml}$ amp, Biofarma, Turkey) and $2 \mathrm{mg} / \mathrm{kg}$ neostigmine (neostigmine methyl sulfate, $0.5 \mathrm{mg} / \mathrm{ml}$, Adeka, Turkey) and were extubated after adequate spontaneous ventilation was observed. They were taken to the recovery room.

On the postoperative $15^{\text {th }}$ min, pain scores, complications (bradycardia, tachycardia, and hypotension) and nausea- vomiting was questioned. The Numerical Rating Scale (NRS) for pain score ${ }^{[6]}$ and nausea-vomiting scale (NVS) were used. ${ }^{[7]}$ Patients with NRS scores higher than 4 were treated with an additional dose of $1 \mathrm{mg} / \mathrm{kg}$ iv tramadol. All patients were routinely administered $0.1 \mathrm{mg} / \mathrm{kg}$ of ondansetron $\mathrm{HCl} 4 \mathrm{mg}$ iv (Zofran, Glaxo Smith Kline, United Kingdom) at the end of the surgery. Patients who suffered from nausea and vomiting (NVS score $>1$ ) were treated with $8 \mathrm{mg}$ dexamethasone IV (Dexamet, Osel Drugs, Turkey).

Patients were transferred to the ward when their Aldrete's scores were $>9 .{ }^{[8]}$ At $1,6,12$, and 24 h postoperatively, patients were evaluated in terms of pain, nausea, vomiting, and also mobility. On the $2^{\text {nd }}$ day, patients were discharged from the hospital, and all patients were called by phone by the same anesthe-

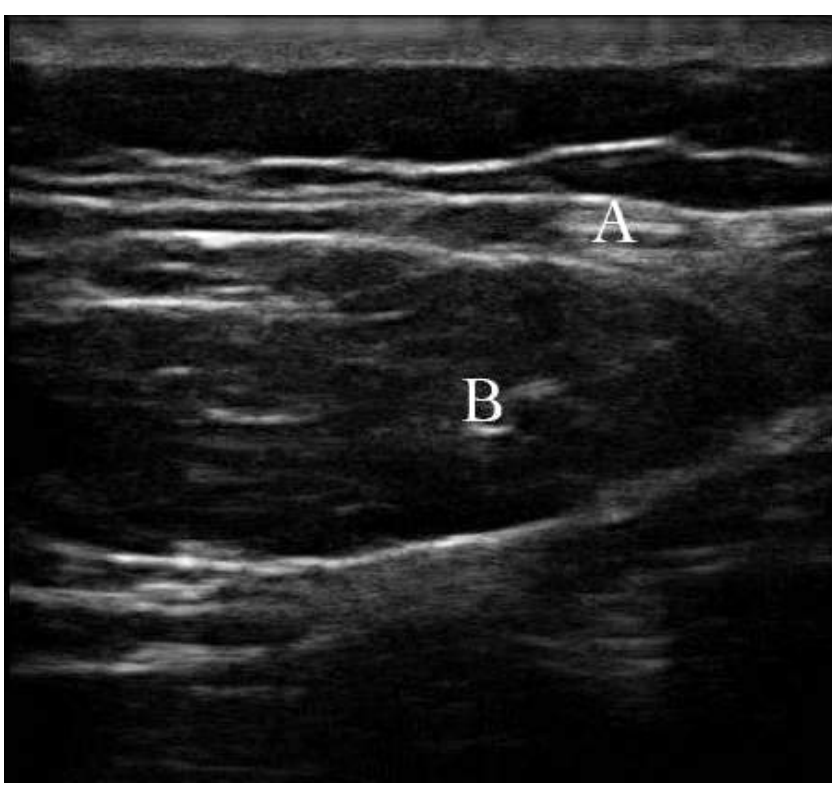

Figure 2. After block. (a) Musculus rectus abdominis. (b) The interfascial space between the musculus rectus abdominis and transversus abdominis after administration of $2 \mathrm{ml}$ of $0.9 \% \mathrm{NaCl}$. 
siologist who had performed the postoperative pain evaluation in the recovery room at 15 and 30 days postoperatively. Their NRS values and quality of life were determined. Quality of life evaluation was done using the SF-36 (short form) Life Quality Form. ${ }^{[9]}$

\section{Statistical analysis}

The Shapiro-Wilk test was used; Histogram, Q-Q plot, and box plot graphics were drawn to test normality. Data are presented as median or mean and standard deviation, minimum, maximum, frequency, and percentage depending on the distribution of variables. Variables with normal distribution between the two groups were analyzed by a t-test (independent sample t-test); others that did not follow a normal distribution were analyzed by the Mann-Whitney $U$ test. Nominal variables were compared by the Fischer's exact probability test, Mc Nemar's test, and Chi-square test with Yates correction. Friedman analysis of variance was used for determining the time dependent variables in the study groups. Wilcoxon signed-rank test with Bonferroni correction was used for multiple comparisons. P value $<0.05$ was considered to be statistically significant. All statistical analyses were performed using SPSS 21 (SPSS, USA).

\section{Sample Size}

We based our sample size calculation on the method used in a previous study, ${ }_{1}^{[10]}$ with a type 1 error of $5 \%$ and power of $80 \%$. With an estimation of a $30 \%$ decrease in NRS scores in group II compared with that in group I and a coefficient of variation of $50 \%$, we considered 0.6 as the effect size (median effect size) and decided to at least include 45 patients in each group. We recruited 50 patients in each group with the expectation of a $10 \%$ dropout and exclusion.

\section{Results}

One hundred seven patients were included to the study from October 2015 to September 2016. One hundred three patients were randomly assigned; however, three patients were later excluded, and a total of one hundred patients were included to the study in final analyses (Fig. 3).

All TAP blocks were performed from the subcostal area with an anterior approach, as described in the material method section. No significant differences were observed in terms of demographic data be- tween the groups (Table 1). No significant difference was observed in the nausea-vomiting scores between groups (Table 2).

Patients in group II were mobilized faster than those in group I (Table 2$)(p=0.009)$. Compared with group II, the analgesic need was higher on postoperative $0-6^{\text {th }}-, 6-12^{\text {th }}$, and $12-24^{\text {th }}-\mathrm{h}$ intervals in group I (Table $2 ; p=0.00$ ). In group II, the additional analgesic need was higher between postoperative $6^{\text {th }}$ and 12th-h interval compared with that between postoperative $0-6^{\text {th }}$ and $12-24^{\text {th }}-\mathrm{h}$ intervals (Table 2) $(p=0.00)$.

Pain Scores: Postoperative $15^{\text {th }}-\min ; 1^{\text {st }}, 6^{\text {th }}-, 12^{\text {th }}$, and $24^{\text {th }}$ - $h ; 15^{\text {th }}$-day $(p=0.00)$ and $1^{\text {st }}$-month NRS values were significantly lower in group II than in group I ( $p=0.02$; Table 3; Fig. 4). No significant difference was observed between the groups in terms of the postoperative $15^{\text {th }}$-day LQS $(p=0.013)$. On group comparison, LQS was higher in the 1st month than at the postoperative $15^{\text {th }}$ day in group I ( $p=0.201$; Table 4$)$.

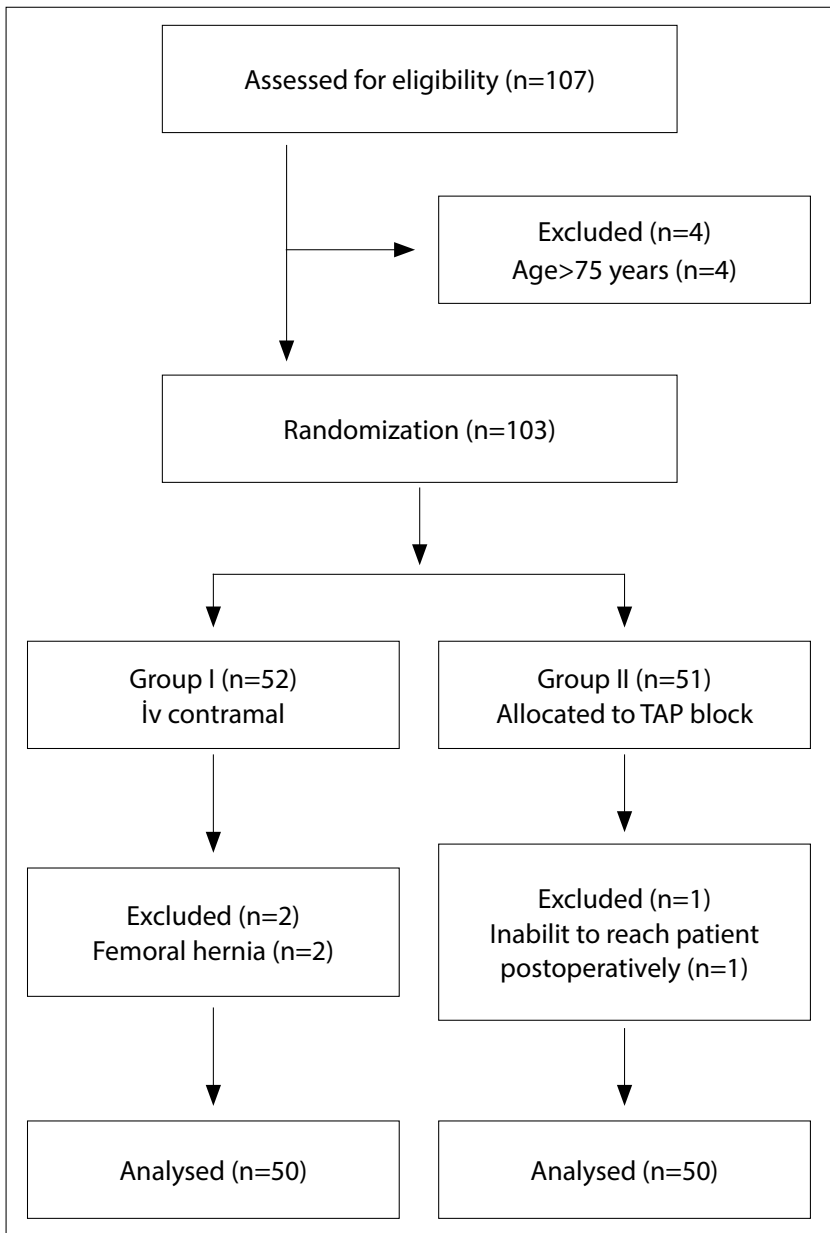

Figure 3. Flow chart of the study. İv, intravenous; TAP, transversus abdominis plane. 


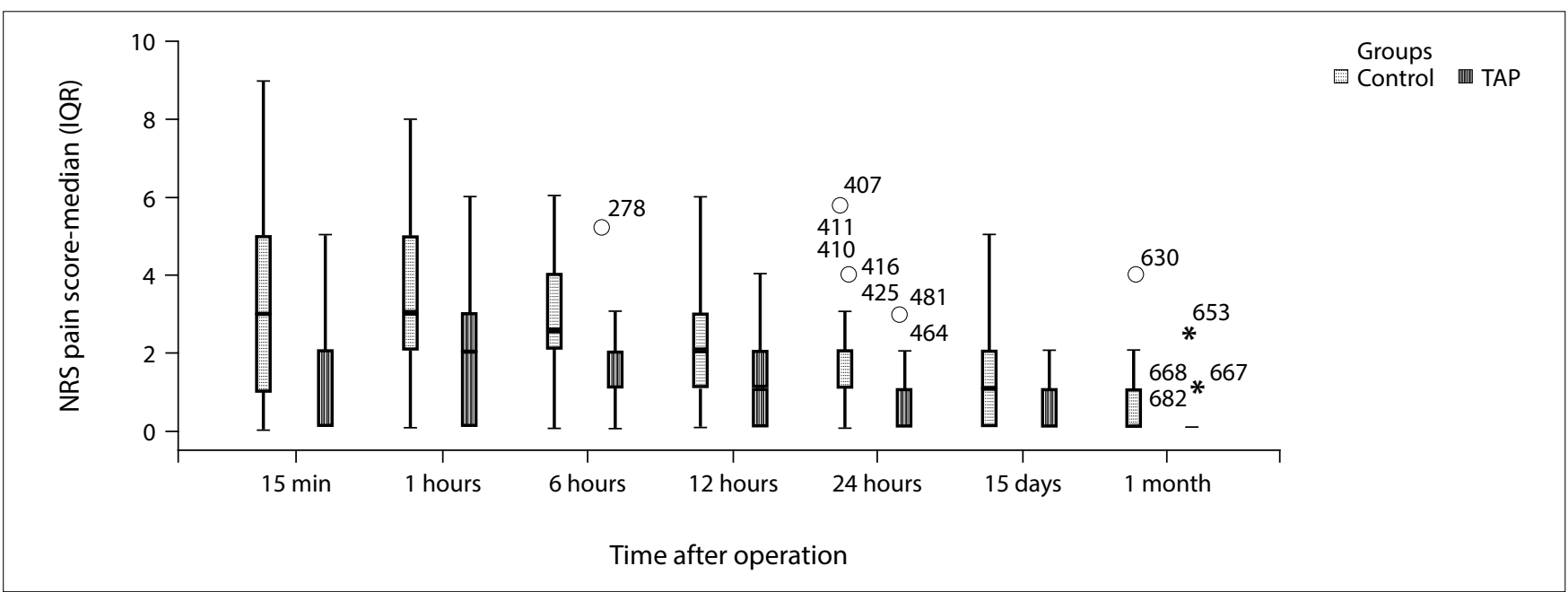

Figure 4. Postoperative numerical rating scores in both groups. Postoperative numerical rating scores of patients in $15^{\text {th }}$ minute, $1 ., 6$. , 12., 24. Hours and 15 and 30 days after operation in both groups. NRS: Numerical rating score; TAP: transversus abdominis plane.

\section{Discussion}

Postoperative chronic pain can be observed in $54 \%$ of the patients following inguinal herniography with mesh. ${ }^{[11]}$ In our study, we aimed to evaluate the effect of TAP block on postoperative acute and subacute pain development in patients who had undergone inguinal herniography. We found that subcostal TAP block performed at the end of the surgery can provide an effective early postoperative analgesia and may decrease postoperative subacute pain development on the $30^{\text {th }}$ postoperative day. This situation may result in the prevention of chronic pain development in this population.

Most of the studies on postoperative acute and chronic pain after inguinal herniography assess the effect of TAP blocks performed in the area between the subcostal line and iliac crest or midaxillary area. ${ }^{[2,}$ ${ }^{12-14]}$ Peterson et al. ${ }^{[12]}$ have compared midaxillary TAP block performed under ultrasonography with ilioinguinal infiltration and placebo group and showed that TAP block is not as effective as ilioinguinal infiltration on postoperative acute pain. Prior studies do not explain why TAP block does not provide an effective postoperative analgesia in patients undergoing inguinal hernia repair. Many studies on patients undergoing inguinal herniography showed that the surgical incision technique and type of "mesh" used can affect persistent postoperative pain development. ${ }^{[2]}$ Ineffectiveness of TAP block in the study by Peterson et al. ${ }^{[12]}$ might have been caused by the volume of study solution $(25 \mathrm{ml})$ and timing of TAP block. Peterson et al. ${ }^{[12]}$ applied TAP block before sur- gical incision; therefore, manipulation of the TAP fascia or any fascial tear during surgery may affect the spread of the local anesthetic solution. In our study, we injected a total of $30 \mathrm{ml}$ of the local anesthetic solution and applied TAP block at the end of surgery in group II patients. Also, we believe that performing TAP block from the midaxillary area may have prevented distribution of the local anesthetic because of obstruction by the mesh and may have inhibited effective postoperative pain therapy. Applying high volumes of the local anesthetic solution while maintaining the same local anesthetic concentration will provide a better distribution of local anesthetics.

Milone et al..$^{[2]}$ showed that postoperative visual analog scale values were significantly lower in patients undergoing inguinal hernia repair in whom TAP block was performed between the subcostal line and iliac crest than in the control group. Although the results of the previous study show some similarity, our study differs in terms of the region of the block and the dose and volume of the local anesthetic used. ${ }^{[2]}$ We believe that when TAP block is performed from the subcostal line with USG in addition to peripheral nerve block, paravertebral distribution of the local anesthetics in the supine position because of its volume effect in accordance with gravity will also provide more effective analgesia. ${ }^{[15]}$ The drug volume has a direct effect on analgesia on plane blocks by increasing the distribution of the drug. ${ }^{[16]}$

Although it has been proved that TAP block is more effective than other methods in relieving pain following inguinal herniography, it still needs to be 
evaluated in terms of indications, technique, drug concentration and volumes, the region of performance, and mechanism of action. ${ }^{[16-18]}$

It was shown that the local anesthetic-contrast media mixture administered to the TAP fascia through the subcostal area was inadequately distributed and did not reach to the paravertebral area. ${ }^{[5]}$ There is a direct effect of the distribution of the local anesthetics inside the TAP fasciae on the analgesic efficacy of the technique. Our results are not concurrent with those of the study by Carney et al. ${ }^{[5]}$ We have acquired efficient postoperative analgesia with subcostal TAP block. We believe that this difference may be due to differences in chemical and physical properties of the local anesthetic-contrast media mixture and local anesthetic-normal saline mixture which may have resulted in the uneven distribution of the mentioned local anesthetic-contrast media mixture. In addition, distribution may differ in patients who underwent surgery under general anesthesia and those who did not receive general anesthesia and stood up right after the procedure. We believe that all these factors may have an impact on the results.

Subcostal TAP blocks can achieve effective postoperative analgesia for $24 \mathrm{~h}$ when performed with the appropriate technique and correct indications. ${ }^{[17-22]}$ We have also shown that an effective postoperative analgesia can prevent subacute pain in the $1^{\text {st }}$ postoperative month and has beneficial results on the quality of life. The analgesic efficacy in the $1^{\text {st }}$ postoperative month may be due to an efficient acute postoperative pain treatment by TAP block that has decreased inflammation in the surgical incision area and may also help in preventing chronic postoperative pain, which must be further investigated with clinical studies.

In group II, the additional analgesic need was higher between the postoperative $6^{\text {th }}$ - and $12^{\text {th }}$-h intervals than at the $0-6^{\text {th }}$ - and $12-24^{\text {th }}$-h intervals. This might be related to earlier mobilization of the patients in group II.

Subcostal TAP block practice for postoperative analgesia in inguinal hernia repair surgeries is a topic that needs to be evaluated with randomized, controlled clinical studies on larger patient populations.
Limitations: A limitation of our study is that we did not perform radiologic imaging to show spread of local anesthetics inside the TAP fascia. It would be better if we could scan the distribution of higher volumes of local anesthetics.

\section{Conclusion}

Subcostal TAP block in higher volumes provides an effective postoperative pain treatment in the acute period and in the $1^{\text {st }}$ postoperative month in patients undergoing inguinal herniography.

\section{Conflict-of-interest issues regarding the authorship or article: None declared.}

\section{Peer-rewiew: Externally peer-reviewed.}

\section{References}

1. Alfieri S, Amid PK, Campanelli G, Izard G, Kehlet H, Wijsmuller AR, et al. International guidelines for prevention and management of post-operative chronic pain following inguinal hernia surgery. Hernia 2011;15(3):239-49.

2. Nienhuijs S, Staal E, Strobbe L, Rosman C, Groenewoud H, Bleichrodt R. Chronic pain after mesh repair of inguinal hernia: a systematic review. Am J Surg 2007;194(3):394400. [CrossRef]

3. van Veen RN, Wijsmuller AR, Vrijland WW, Hop WC, Lange $J F$, Jeekel J. Randomized clinical trial of mesh versus nonmesh primary inguinal hernia repair: long-term chronic pain at 10 years. Surgery 2007;142(5):695-8. [CrossRef]

4. Tekelioğlu UY, Demirhan A, Koçoğlu H. Transversus Abdominis Plane (TAP) Block. Abant Med J 2013;2(2):156-60.

5. Carney J, Finnerty O, Rauf J, Bergin D, Laffey JG, Mc Donnell JG. Studies on the spread of local anaesthetic solution in transversus abdominis plane blocks. Anaesthesia 2011;66(11):1023-30. [CrossRef]

6. Hjermstad MJ, Fayers PM, Haugen DF, Caraceni A, Hanks GW, Loge JH, et al; European Palliative Care Research Collaborative (EPCRC). Studies comparing Numerical Rating Scales, Verbal Rating Scales, and Visual Analogue Scales for assessment of pain intensity in adults: a systematic literature review. J Pain Symptom Manage 2011;41(6):1073-93.

7. Gürses E, Serin S, Tomatır E, Balcı C, Gönüllü M. A Comparison of Metoclopramide, Droperidol And Ondansetron in The Prevention of Nausea and Vomiting Releated to Tramadol. The Medical Journal of Kocatepe 2003;2:23-8.

8. Aldrete JA. The post-anesthesia recovery score revisited. J Clin Anesth 1995;7(1):89-91. [CrossRef]

9. Iudici M, Cuomo G, Vettori S, Avellino M, Valentini G. Quality of life as measured by the short-form 36 (SF-36) questionnaire in patients with early systemic sclerosis and undifferentiated connective tissue disease. Health Qual Life Outcomes 2013;11:23. [CrossRef]

10. Salman $A E$, Yetişir $F$, Yürekli $B$, Aksoy $M$, Yildirim $M$, Kiliç $M$. 
The efficacy of the semi-blind approach of transversus abdominis plane block on postoperative analgesia in patients undergoing inguinal hernia repair: a prospective randomized double-blind study. Local Reg Anesth 2013;6:1-7.

11. Poobalan AS, Bruce J, Smith WC, King PM, Krukowski ZH, Chambers WA. A review of chronic pain after inguinal herniorrhaphy. Clin J Pain 2003;19(1):48-54. [CrossRef]

12. Petersen $P L$, Mathiesen $O$, Stjernholm $P$, Kristiansen VB, Torup $\mathrm{H}$, Hansen EG, et al. The effect of transversus abdominis plane block or local anaesthetic infiltration in inguinal hernia repair: a randomised clinical trial. Eur J Anaesthesiol 2013;30(7):415-21. [CrossRef]

13. Milone M, Di Minno MN, Musella M, Maietta $P$, Salvatore $G$, lacovazzo $C$, et al. Outpatient inguinal hernia repair under local anaesthesia: feasibility and efficacy of ultrasound-guided transversus abdominis plane block. Hernia 2013;17(6):749-55. [CrossRef]

14. Aveline $C$, Le Hetet $H$, Le Roux A, Vautier P, Cognet F, Vinet $E$, et al. Comparison between ultrasound-guided transversus abdominis plane and conventional ilioinguinal/iliohypogastric nerve blocks for day-case open inguinal hernia repair. Br J Anaesth 2011;106(3):380-6. [CrossRef]

15. Forero M, Heikkila A, Paul JE, Cheng J, Thabane L. Lumbar transversus abdominis plane block: the role of local anesthetic volume and concentration-a pilot, prospective, randomized, controlled trial. Pilot Feasibility Stud 2015;1:10.

16. Petersen PL, Mathiesen O, Torup H, Dahl JB. The transversus abdominis plane block: a valuable option for postoperative analgesia? A topical review. Acta Anaesthesiol Scand
2010;54(5):529-35. [CrossRef]

17. Sujatha C, Zachariah M, Ranjan RV, George SK, Ramachandran TR, Pillai AR. Transversus Abdominis Plane Block versus Ilioinguinal/Iliohypogastric Nerve Block with Wound Infiltration for Postoperative Analgesia in Inguinal Hernia Surgery: A Randomized Clinical Trial. Anesth Essays Res 2017;11(4):976-80. [CrossRef]

18. Aguirre-Ospinaa OD, Gómez-Salgadob JC, Chaverrab D, Alzateb M, Ríos-Medinab AM. TAP block in inguinal hernia repair. Randomized controlled trial. Rev Colomb Anestesiol 2017;45:159-65. [CrossRef]

19. El-Dawlatly AA, Turkistani A, Kettner SC, Machata AM, Delvi $M B$, Thallaj $A$, et al. Ultrasound-guided transversus abdominis plane block: description of a new technique and comparison with conventional systemic analgesia during laparoscopic cholecystectomy. $\mathrm{Br} J$ Anaesth 2009;102(6):763-7. [CrossRef]

20. McDonnell JG, Curley G, Carney J, Benton A, Costello J, Maharaj $\mathrm{CH}$, et al. The analgesic efficacy of transversus abdominis plane block after cesarean delivery: a randomized controlled trial. Anesth Analg 2008;106(1):186-91. [CrossRef]

21. O'Donnell BD, McDonnell JG, McShane AJ. The transversus abdominis plane (TAP) block in open retropubic prostatectomy. Reg Anesth Pain Med 2006;31(1):91. [CrossRef]

22. Ekmekçi $P$, Kazak Bengisun Z, Kazbek BK, Han S, Tüzüner F. Ultrasound guided TAP block for the treatment of postoperative prolonged pain - an alternative approach. Agri 2012;24(4):191-3. [CrossRef] 